\title{
POTENCIÁL ROZŠÍRENIA MALOOBCHODNÝCH SIETÍ DO MENŠÍCH OBCÍ NA SLOVENSKU
}

\author{
Monika Ďugelová ${ }^{1}$ - Mariana Strenitzerová ${ }^{2}$
}

\section{Úvod}

V súčasnom období globalizácie a internacionalizácie a rozvoja informačných technológií riešia mnohé obchodné podniky problém d'alšieho smerovania. Majú možnost' zamerat' sa na výstavbu nových kamenných obchodov a pokračovat' v tradícii alebo vstúpit' do neznámych vôd elektronického podnikania a začat' využívat' dostupné informačné technológie. Dôvodom je silnejúca pozícia konkurencie na trhu a jej expanzia do stále menších obcí. Taktiež sledovaná spoločnost', maloobchodný ret'azec pôsobiaci na slovenskom trhu už viac ako 17 rokov, hl'adá stále nové koncepcie rozvoja a rozširovania svojej maloobchodnej siete.

\section{Analýza súčasného stavu}

Samotné rozmiestnenie zariadení maloobchodu a výber ich štandardov sa riadi filozofiou diferencovanej, ale komplexnej ponuky podl'a vel'kostnej kategórie obce. Optimalizácia obchodnej siete $\mathrm{v}$ obciach podla metodickej príručky Štandardy minimálnej vybavenosti obcí z dielne Inštitútu urbanizmu a územného plánovania URBION vychádza z optimalizácie na úrovni okresov, pričom predmetom optimalizácie býva predovšetkým vel'kost' predajnej plochy a formát. Prihliada sa na demografické a socio-ekonomické rozdiely medzi regiónmi a kúpnu silu obyvatel'stva [1].

Sledovaná maloobchodná spoločnost' sa pri výbere lokalít snaží vychádzat' z územných plánov a metodických príručiek, pričom rozmiestnenie prevádzok je vel'mi nerovnomerné. Vel'ké diery sú na juhu, západe a severe Slovenska, kde nemá takmer žiadne prevádzky, konkurencia tu už ale začala obsadzovat' viaceré obce.

Ako možno vidiet' na obrázku č. 1, spoločnost' má spolu 133 prevádzok, z toho 54 hypermarketov, 5 obchodných domov, 41 supermarketov, 8 vel'kých hypermarketov a 25 malých supermarketov. Čo sa týka vel'kostí obcí, expanduje oproti konkurencii aj do obcí s vel'kost'ou pod 4000 obyvatel'ov, v súčasnosti do tejto kategórie spadá supermarket v Chorvátskom Grobe (3162 obyvatel'ov) a malý supermarket v dedine Pate (3104 obyvatel'ov). V hlavnom meste Bratislava má 22 prevádzok, $\mathrm{z}$ toho väčšina je formátu malého supermarketu [2].

\footnotetext{
${ }^{1}$ Ing. Monika Ďugelová, Žilinská univerzita v Žiline, Fakulta prevádzky a ekonomiky dopravy a spojov, Katedra spojov, Univerzitná 1, 01026 Žilina, tel. 041 5133145, e-mail: monika.dugelova @ fpedas.uniza.sk ${ }^{2}$ doc. Ing. Mariana Strenitzerová, PhD., Žilinská Univerzita v Žiline, Fakulta prevádzky a ekonomiky dopravy a spojov, Katedra spojov, Univerzitná 1, 01026 Žilina, Slovenská republika tel. 00421-041-5133 131, fax 00421-041-5655 615, e-mail: Mariana.Strenitzerova @fpedas.uniza.sk
} 
Zaujímavý z pohl'adu expanzie je tiež pohl'ad na preferované formáty zo strany zákazníkov. Podla výskumu agentúry INCOMA GFK uskutočňovaného v roku 2012 vo vybraných európskych štátoch - na Slovensku, ako v mestských, tak i vidieckych oblastiach, je preferovaným formátom malá predajňa (32\% opýtaných). $28 \%$ respondentov uvádza ako svoje hlavné nákupné miesto hypermarket a $27 \%$ supermarket. Naproti tomu v Českej republike vedie hypermarket, kde najčastejšie nakupuje takmer polovica opýtaných. V súčasnosti však obyvatelia upúštajú od nákupov vo vel'koformátových prevádzkach a navštevujú skôr supermarkety a menšie pultové predajne, ktoré majú síce obmedzenú ponuku, nachádzajú sa ale bližšie ich bydlisku či zamestnaniu $[4,5,6,7]$.

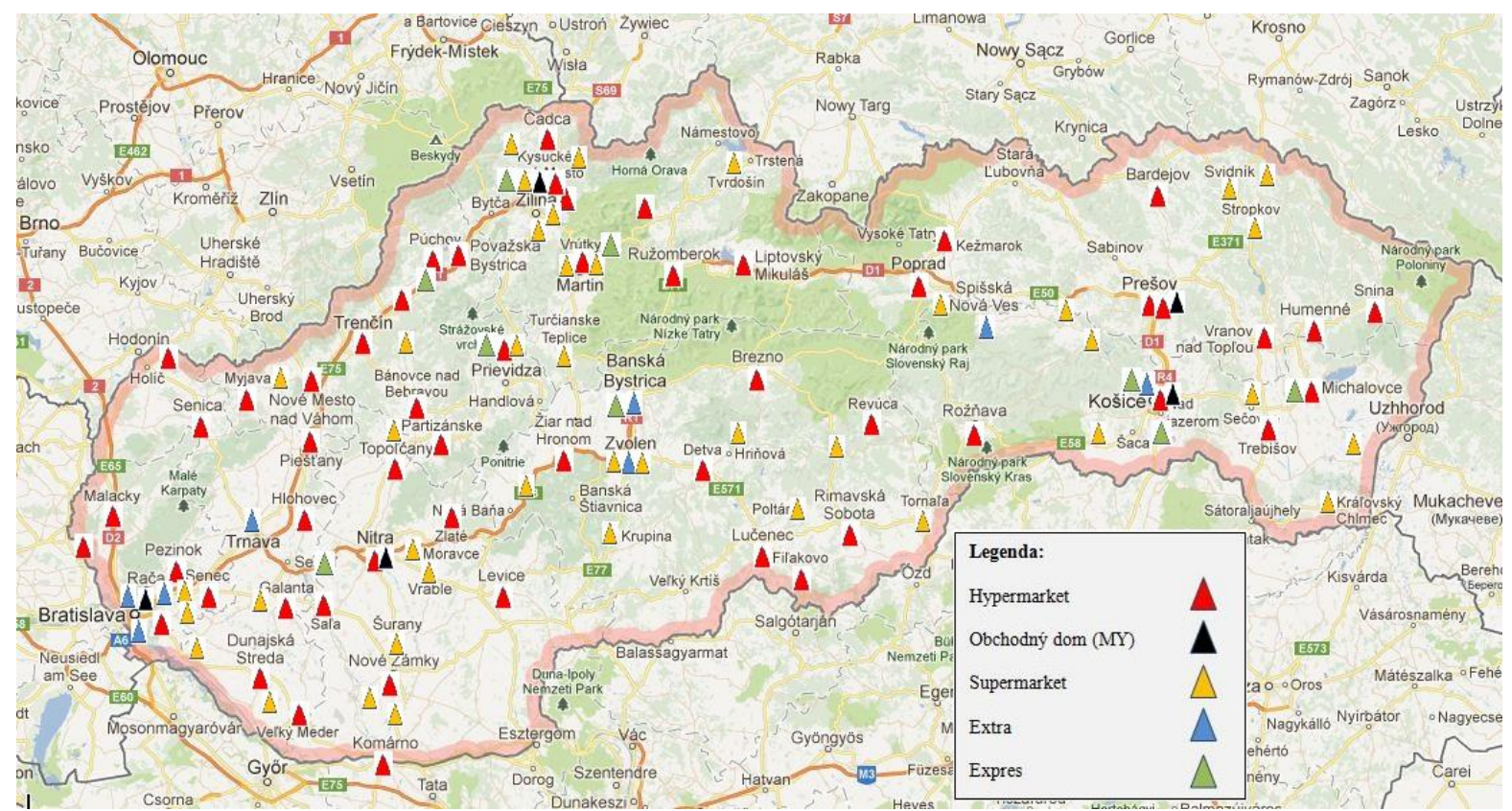

Obrázok 1 Prevádzky spoločnosti Tesco v slovenských mestách s rozdelením podl’a formátu prevádzok k 10.3.2013 (Zdroj: TESCO: Obchody.[online]. [cit. 2013-03-10]. Dostupné na internete: <http://www.itesco.sk/sk/tesco-v-sr/o-nas/profil/>,Vlastné spracovanie)

Možnosti expanzie stále existujú, čo priznáva aj samotná spoločnost'. Z väčších miest nad 10.000 obyvatel'ov je to napríklad Sabinov na východe a Kysucké Nové Mesto na severe Slovenska. Z obcí s menej ako 10.000 obyvatel'mi sú to napríklad Trstená alebo Námestovo v oblasti Oravy. Za zmienku stoja aj turisticky zaujímavé miesta ako sú historické mestá, kúpel'né mestá alebo sídla v blízkosti turistických trás a lyžiarskych stredísk.

\section{Ciel' a riešenie výskumu}

Pre preskúmanie možnosti rozšírenia obchodnej siete spoločnosti do jednotlivých obcí na Slovensku bolo potrebné identifikovat' kritériá vhodného umiestnenia. Na základe ich použitia a určenia hraničných hodnôt sme vypracovali konkrétny návrh rozšírenia maloobchodnej siete, čo bolo aj ciel'om nášho výskumu.

Pri spracovaní načrtnutého problému sme sa zamerali na posudzovanie obcí v Slovenskej republike podl'a určitých kritérií vychádzajúc z analýzy súčasného stavu na Slovensku av zahraničí a z predchádzajúcich výskumov, najmä od českého autora $\mathrm{Z}$. Szczyrbu (dielo Venkovský obchod v ČR v podmínkach ekonomické transformace z roku 2002 a Současná situace v maloobchodní siti českých měst - Geografická sonda Zlín z roku 2006) alebo kolektívu autorov V. Lauko, L. Tomáči, F. Križan (výskum z roku 2008 publikovaný pod názvom Potravinársky maloobchod na Slovensku: rurálne prostredie, čas a miesto nákupu). 
Základným kritériom bola vel'kost' obcí. Pre určenie dolného limitu sme zvolili metódu individuálneho rozhovoru. Riadiaci pracovník spoločnosti považuje za zmysluplné zamysliet' sa nad expanziou do obcí nad 3500 obyvatel'ov. K týmto obciam sme podl'a vlastného uváženia pridali aj obce s menším počtom obyvatel'ov, ktoré sú turisticky prít'ažlivé a majú podl'a nás potenciál k výstavbe prevádzky spoločnosti. Do zoznamu sme tak zaradili aj Slovenský Grob, Rajecké Teplice, Krásnohorské Podhradie, Oravský Podzámok, Topol'čianky a Orechovú Potôn. Nové prevádzky v týchto turisticky atraktívnych oblastiach zvýšia občiansku vybavenost' miest a atraktívnost' pre zahraničných turistov, ktorí poznajú siet' spoločnosti z domova.[8]

Druhá séria kritérií vychádzala $\mathbf{z}$ geografických a sociálno-ekonomických faktorov, ktoré možno zistit' z dostupných štatistických zdrojov. Z geografických faktorov sa zist'oval počet obyvatel'ov a spádovost' obce, zo sociálno-ekonomických kúpyschopnost' obyvatel'stva (priemerná mesačná nominálna mzda $v €$ a priemerná mesačná výška výdavkov na potraviny, nápoje a tabak $v €$ ) a koeficient vybavenosti územia.

Poslednú sériu tvorili kritériá vlastné spoločnosti a jej maloobchodnej sieti, a to vzdialenost' najbližšieho hypermarketu a počet prevádzok $\mathbf{v}$ danej obci. Pri týchto kritériách sme vychádzali z oficiálnej stránky spoločnosti a analýzy lokalizácie jej prevádzok. $\mathrm{Na}$ základe posudzovaných kritérií a ich hraničných hodnôt vychádzajúcich $\mathrm{z}$ dostupných výskumov a metodík bolo možné definovat' tri skupiny obcí vhodných pre rozš́renie maloobchodnej siete. Do prvej skupiny, najvhodnejšej pre expanziu, sme zaradili obce s počtom obyvatel'ov nad 3500, ktoré nemajú na svojom území zatial' žiadnu prevádzku vybranej spoločnosti, sú vzdialené aspoň $10 \mathrm{~km}$ od najbližšieho hypermarketu, majú status obce ako spádového centra a vúrovni kúpyschopnosti patria $\mathrm{k}$ lepšej polovici (podl'a priemernej výšky nominálnej mzdy a výšky výdavkov na potraviny, nápoje a tabak za jednotlivé kraje za rok 2009 dostupných na stránke Štatistického úradu Slovenskej republiky), pričom museli splnit' aspoň tri kritériá.

Druhou skupinou boli okresné mestá, čiže spádové centrá, ktoré majú na svojom území už prevádzku posudzovanej spoločnosti (maximálne ale jednu) a úroveň vybavenosti územia pod $0,29 \mathrm{~m}^{2}$ na obyvatel'a. Do tretej skupiny sme zaradili obce menšie svojou rozlohou aj počtom obyvatel'ov, ktoré dosahujú horšie výsledky v sledovaných charakteristikách, sú ale významné z hl'adiska svojej polohy alebo zaujímavosti z pohl'adu cestovného ruch [3].

\section{Vlastný návrh}

Po vyselektovaní obcí vhodných pre expanziu a d'alšiu expanziu sa určoval formát prevádzok, kedy sa brali do úvahy nielen odporúčania metodickej príručky, ale aj vzdialenost' najbližšieho hypermarketu, počet prevádzok konkurencie a počet a formát už existujúcich prevádzok spoločnosti. Dôležité bolo taktiež vnímat' obec ako súčast' celku (okresu a kraja) a pozerat' sa na hustotu maloobchodnej siete v oblasti a kúpnu silu obyvatel'stva.

Pri prvej skupine oblastí vhodných pre expanziu sme dbali najmä na počet konkurenčných prevádzok a na vzdialenost' k najbližšiemu hypermarketu. Obce nachádzajúce sa bližšie k väčším mestám nepotrebujú také vysoké pokrytie, lebo vel'a l'udí aj tak nakupuje v mestách, kde pracujú a študujú alebo iba chodia na nákupy. Naopak, pre obce nachádzajúce sa viac ako $20 \mathrm{~km}$ od najbližšieho hypermarketu je potrebné zabezpečit' väčšiu prevádzku, kde by mohli uskutočnit’ aj týždenné nákupy.

Pri rozhodovaní o formátoch $\mathbf{v}$ druhej skupine oblastí vhodných pre expanziu sme pozerali v prvom rade na počet obyvatel'ov a formát už zriadenej prevádzky, ale tiež na hustotu maloobchodnej siete v okolí. Napríklad pre Nové Mesto nad Váhom sme aj napriek vysokému počtu obyvatel'ov a malému množstvu prevádzok posudzovanej spoločnosti, 
odporučili iba menší formát, ked’že v meste má dost' prevádzok konkurencia a nachádza sa v oblasti západného Slovenska s vysokou koncentráciou rôznych ret’azcov a sietí.

Tretia skupina oblastí bola významná z hl’adiska svojho významu a boli tu zaradené obce s menším počtom obyvatel'ov. Snažili sme sa do nich odporučit' iba menšie formáty, najmä malý supermarket s predajnou plochou 300 alebo $400 \mathrm{~m}^{2}$, ojedinele väčšie.

Predpokladali sme, že najmä turisticky oblúbené obce majú vel'a turistov iba v určitej sezóne a v určitej časti roku sa v obci nachádzajú iba stáli obyvatelia, ktorí nemajú takú vysokú kúpnu silu. Stačí preto prevádzka menšieho formátu, ktorá zvládne nápor turistov a zvyšnú čast' roka bude slúžit' ako klasický obchod pre obyvatel'ov.

Samotné obce s návrhom pre rozšírenie prevádzok a ich počtom sa nachádza v nasledujúcej tabul'ke.

Tabul'ka 1 Zoznam vyselektovaných obcí s odporúčanými formátmi a počtom prevádzok

\begin{tabular}{|c|c|c|c|c|c|}
\hline Obec & Odporúčaný formát & Počet & Obec & Odporúčaný formát & Počet \\
\hline Rohožník & $\begin{array}{c}\text { malý supermarket } \\
500 \mathrm{~m}^{2}\end{array}$ & 1 & Senica & $\begin{array}{c}\text { malý supermarket } \\
600 / 1000 \mathrm{~m}^{2}\end{array}$ & 1 \\
\hline Stupava & $\begin{array}{c}\text { malý supermarket } \\
600 / 1000 \mathrm{~m}^{2}\end{array}$ & 1 & Skalica & $\begin{array}{c}\text { vel'ký supermarket / } \\
\text { obchodný dom }\end{array}$ & 1 \\
\hline Cífer & $\begin{array}{c}\text { malý supermarket } \\
500 \mathrm{~m}^{2}\end{array}$ & 1 & $\begin{array}{c}\text { Bánovce nad } \\
\text { Bebravou }\end{array}$ & $\begin{array}{c}\text { malý supermarket } \\
600 / 1000 \mathrm{~m}^{2}\end{array}$ & 1 \\
\hline Ilava & $\begin{array}{l}\text { malý supermarket } \\
1000 \mathrm{~m}^{\mathbf{2}}\end{array}$ & 1 & Myjava & $\begin{array}{c}\text { malý supermarket } \\
500 / 600 \mathrm{~m}^{2}\end{array}$ & 1 \\
\hline Vel'ké Zálužie & $\begin{array}{l}\text { malý supermarket } \\
500 \mathrm{~m}^{2}\end{array}$ & 1 & $\begin{array}{l}\text { Nové Mesto } \\
\text { nad Váhom }\end{array}$ & $\begin{array}{c}\text { malý supermarket } \\
600 / 1000 \mathrm{~m}^{2}\end{array}$ & 1 \\
\hline Cabaj-Čápor & $\begin{array}{c}\text { malý supermarket } \\
500 \mathrm{~m}^{2}\end{array}$ & 1 & Partizánske & malý supermarket & 1 \\
\hline Močenok & $\begin{array}{c}\text { malý supermarket } \\
600 / 1000 \mathrm{~m}^{2} \\
\end{array}$ & 1 & $\begin{array}{l}\text { Považská } \\
\text { Bystrica }\end{array}$ & vel'ký supermarket & 1 \\
\hline Terchová & $\begin{array}{c}\text { malý supermarket } \\
600 / 1000 \mathrm{~m}^{2}\end{array}$ & 1 & Púchov & malý supermarket & 1 \\
\hline Varín & $\begin{array}{c}\text { malý supermarket } \\
600 / 1000 \mathrm{~m}^{2} \\
\end{array}$ & 1 & Levice & $\begin{array}{c}\text { vel'ký supermarket / } \\
\text { obchodný dom }\end{array}$ & 1 \\
\hline Bytča & $\begin{array}{c}\text { malý supermarket } \\
1000 \mathrm{~m}^{\mathrm{z}}\end{array}$ & 1 & Topol'čany & malý supermarket & 1 \\
\hline $\begin{array}{c}\text { Kysucké Nové } \\
\text { Mesto }\end{array}$ & $\begin{array}{l}\text { vel'ký supermarket / } \\
\text { obchodný dom }\end{array}$ & 1 & Dolný Kubín & vel'ký supermarket & 1 \\
\hline Námestovo & $\begin{array}{c}\text { vel'ký supermarket / } \\
\text { malý hypermarket }\end{array}$ & 1 & $\begin{array}{c}\text { Liptovský } \\
\text { Mikuláš }\end{array}$ & $\begin{array}{l}\text { vel'ký supermarket / } \\
\text { obchodný dom }\end{array}$ & 1 \\
\hline Vel'ký Krtíš & $\begin{array}{c}\text { vel'ký supermarket / } \\
\text { malý hypermarket / } \\
\text { obchodný dom }\end{array}$ & 1 & Ružomberok & $\begin{array}{l}\text { vel'ký supermarket / } \\
\text { obchodný dom }\end{array}$ & 1 \\
\hline Nová Baňa & $\begin{array}{l}\text { malý supermarket / } \\
\text { vel'ký supermarket }\end{array}$ & 1 & $\begin{array}{l}\text { Žiar nad } \\
\text { Hronom }\end{array}$ & vel'ký supermarket & 1 \\
\hline $\begin{array}{l}\text { Banská } \\
\text { Štiavnica }\end{array}$ & $\begin{array}{l}\text { vel'ký supermarket / } \\
\text { obchodný dom }\end{array}$ & 1 & Brezno & vel'ký supermarket & 1 \\
\hline Stará L'ubovňa & vel'ký supermarket & 1 & Lučenec & vel'ký supermarket & 1 \\
\hline Levoča & vel'ký supermarket & 1 & Revúca & $\begin{array}{c}\text { malý supermarket } \\
600 / 1000 \mathrm{~m}^{2}\end{array}$ & 1 \\
\hline Vysoké Tatry & $\begin{array}{c}\text { malý supermarket } \\
400 / 500 \mathrm{~m}^{\mathbf{2}}\end{array}$ & 1 & Stropkov & $\begin{array}{c}\text { vel'ký supermarket / } \\
\text { malý hypermarket }\end{array}$ & 1 \\
\hline Sabinov & $\begin{array}{l}\text { vel'ký supermarket / } \\
\text { malý hypermarket }\end{array}$ & 1 & Svidník & $\begin{array}{l}\text { vel'ký supermarket / } \\
\text { malý hypermarket }\end{array}$ & 1 \\
\hline
\end{tabular}

Zdroj: Vlastné spracovanie 
Tabul'ka 1 Zoznam vyselektovaných obcí s odporúčanými formátmi a počtom prevádzok - pokračovanie tabul'ky

\begin{tabular}{|c|c|c|c|c|c|}
\hline Obec & Odporúčaný formát & Počet & Obec & Odporúčaný formát & Počet \\
\hline $\begin{array}{l}\text { Čierna nad } \\
\text { Tisou }\end{array}$ & $\begin{array}{l}\text { malý supermarket } \\
500 \mathrm{~m}^{2}\end{array}$ & 1 & $\begin{array}{l}\text { Vranov nad } \\
\text { Topl'ou }\end{array}$ & $\begin{array}{c}\text { malý supermarket } \\
600 / 1000 \mathrm{~m}^{2}\end{array}$ & 1 \\
\hline $\begin{array}{c}\text { Košice - } \\
\text { mestská čast' } \\
\text { Šaca }\end{array}$ & $\begin{array}{c}\text { malý supermarket } \\
600 / 1000 \mathrm{~m}^{2}\end{array}$ & 1 & Humenné & vel'ký supermarket & 1 \\
\hline Medzev & $\begin{array}{c}\text { malý supermarket } \\
400 / 500 \mathrm{~m}^{2}\end{array}$ & 1 & Medzilaborce & $\begin{array}{c}\text { malý supermarket } \\
500 / 600 \mathrm{~m}^{2}\end{array}$ & 1 \\
\hline $\begin{array}{c}\text { Turňa nad } \\
\text { Bodvou }\end{array}$ & $\begin{array}{c}\text { malý supermarket } \\
400 / 500 \mathrm{~m}^{2}\end{array}$ & 1 & Modra & $\begin{array}{c}\text { malý supermarket } \\
500 / 600 \mathrm{~m}^{2}\end{array}$ & 1 \\
\hline Dobšiná & $\begin{array}{c}\text { malý supermarket } \\
400 / 500 \mathrm{~m}^{2}\end{array}$ & 1 & Vel'ký Meder & $\begin{array}{c}\text { malý supermarket } \\
500 / 600 \mathrm{~m}^{2}\end{array}$ & 1 \\
\hline Sobrance & $\begin{array}{c}\text { malý supermarket } \\
500 / 600 \mathrm{~m}^{2}\end{array}$ & 1 & $\begin{array}{l}\text { Orechová } \\
\text { Potôn̆ }\end{array}$ & $\begin{array}{l}\text { malý supermarket } \\
300 \mathrm{~m}^{2}\end{array}$ & 1 \\
\hline Malacky & $\begin{array}{c}\text { malý supermarket } \\
600 / 1000 \mathrm{~m}^{2}\end{array}$ & $2 / 1$ & Šaštín-Stráže & $\begin{array}{c}\text { malý supermarket } \\
600 / 1000 \mathrm{~m}^{2}\end{array}$ & 1 \\
\hline Hlohovec & $\begin{array}{l}\text { malý supermarket } \\
\qquad 500 \mathrm{~m}^{2}\end{array}$ & 1 & Bojnice & $\begin{array}{c}\text { malý supermarket } \\
600 / 1000 \mathrm{~m}^{2}\end{array}$ & 1 \\
\hline Trnava & $\begin{array}{c}\text { malý supermarket } \\
600 / 1000 \mathrm{~m}^{2}\end{array}$ & $2 / 1$ & $\begin{array}{c}\text { Trenčianske } \\
\text { Teplice }\end{array}$ & $\begin{array}{c}\text { malý supermarket } \\
500 / 600 \mathrm{~m}^{2}\end{array}$ & 1 \\
\hline Trenčín & $\begin{array}{l}\text { vel'ký supermarket / } \\
\text { obchodný dom / malý } \\
\text { supermarket } 600 \mathrm{~m}^{\mathbf{2}}\end{array}$ & $1 / 1 / 3$ & Štúrovo & $\begin{array}{c}\text { malý supermarket } \\
600 / 1000 \mathrm{~m}^{2}\end{array}$ & 1 \\
\hline Šal’a & $\begin{array}{c}\text { malý supermarket } \\
500 / 600 \mathrm{~m}^{\mathbf{2}}\end{array}$ & $2 / 1$ & Topol'čianky & $\begin{array}{l}\text { malý supermarket } \\
300 \mathrm{~m}^{\mathbf{2}}\end{array}$ & 1 \\
\hline Žarnovica & $\begin{array}{l}\text { malý supermarket } \\
500 \mathrm{~m}^{2}\end{array}$ & 2 & $\begin{array}{l}\text { Rajecké } \\
\text { Teplice }\end{array}$ & $\begin{array}{c}\text { malý supermarket } \\
300 / 400 \mathrm{~m}^{2}\end{array}$ & 1 \\
\hline Detva & $\begin{array}{c}\text { malý supermarket } \\
500 / 600 \mathrm{~m}^{2}\end{array}$ & $2 / 1$ & Turzovka & $\begin{array}{c}\text { malý supermarket } \\
500 / 600 \mathrm{~m}^{2}\end{array}$ & 1 \\
\hline Detva & $\begin{array}{c}\text { malý supermarket } \\
500 / 600 \mathrm{~m}^{\mathbf{z}}\end{array}$ & $2 / 1$ & Turzovka & $\begin{array}{c}\text { malý supermarket } \\
500 / 600 \mathrm{~m}^{\mathbf{2}}\end{array}$ & 1 \\
\hline Poprad & $\begin{array}{l}\text { vel'ký supermarket / } \\
\text { obchodný dom / malý } \\
\text { supermarket } 600 \mathrm{~m}^{\mathbf{2}}\end{array}$ & $1 / 1 / 3$ & $\begin{array}{l}\text { Turčianske } \\
\text { Teplice }\end{array}$ & $\begin{array}{c}\text { malý supermarket } \\
400 / 500 m^{2}\end{array}$ & 1 \\
\hline Trebišov & $\begin{array}{c}\text { malý supermarket } \\
500 / 600 \mathrm{~m}^{2}\end{array}$ & $2 / 1$ & Čierny Balog & $\begin{array}{c}\text { malý supermarket } \\
400 / 500 \mathrm{~m}^{2}\end{array}$ & 1 \\
\hline Rožňava & $\begin{array}{c}\text { malý supermarket } \\
600 / 1000 \mathrm{~m}^{2}\end{array}$ & $2 / 1$ & $\begin{array}{c}\text { Vel'ká } \\
\text { Lomnica }\end{array}$ & $\begin{array}{c}\text { malý supermarket } \\
400 / 500 \mathrm{~m}^{2}\end{array}$ & 1 \\
\hline Senec & $\begin{array}{c}\text { malý supermarket } \\
500 / 600 \mathrm{~m}^{2}\end{array}$ & $2 / 1$ & $\begin{array}{c}\text { Spišské } \\
\text { Podhradie }\end{array}$ & $\begin{array}{c}\text { malý supermarket } \\
300 / 400 \mathrm{~m}^{2}\end{array}$ & 1 \\
\hline Galanta & $\begin{array}{c}\text { malý supermarket } \\
500 / 600 \mathrm{~m}^{2}\end{array}$ & $2 / 1$ & Štrba & $\begin{array}{c}\text { malý supermarket } \\
300 / 400 \mathrm{~m}^{2}\end{array}$ & 1 \\
\hline Piešt'any & $\begin{array}{l}\text { malý supermarket } \\
1000 \mathrm{~m}^{2}\end{array}$ & 1 & $\begin{array}{c}\text { Oravský } \\
\text { Podzámok }\end{array}$ & $\begin{array}{c}\text { malý supermarket } \\
300 / 400 \mathrm{~m}^{\mathbf{2}}\end{array}$ & 1 \\
\hline
\end{tabular}

\section{Zdroj: Vlastná spracovanie}

Samotná výstavba prevádzok by mala podla štúdie uskutočnitel’nosti prebiehat' $\mathrm{v}$ štyroch fázach:

1. Predinvestičná fáza - v predinvestičnej fáze bude potrebné nájst' vhodné pozemky pre výstavbu $\mathrm{v}$ danej obci a o zámere investovat $\mathrm{v}$ obci rokovat' $\mathrm{s}$ miestnym zastupitel'stvom. 
2. Investičná fáza $-v$ investičnej fáze sa už budú uskutočňovat' prvé reálne prípravy, čiže bude potrebné odkúpit' pozemky, vybavit' potrebné stavebné povolenia, naplánovat' výstavbu so stavebnou firmou a oboznámit' občanov s investičným zámerom.

3. Realizácia - realizácia predstavuje samotnú výstavbu prevádzky a následný nábor a zaškolenie zamestnancov.

4. Porealizačná fáza - po vystavení prevádzky a jej spustení je možné merat' úspešnost' investičného zámeru návratnost'ou investícií (ROI), spokojnost’ou zákazníkov alebo počtom nových pracovných miest $\mathrm{v}$ regióne.

Vo všetkým fázach výstavby je okrem toho dôležitá otvorená komunikácia s obecným zastupitel'stvom a zákazníkmi, ktorá umožní oboznámit' všetky zainteresované strany $\mathrm{v}$ dostatočnom predstihu s výstavbou a z nej vyplývajúcimi zmenami a vyhnút' sa tak vzniku nedorozumení a negatívneho prijatia.

\section{Záver}

Stav maloobchodnej siete na Slovensku môžeme definovat' ako uspokojivý, aj ked' stále existuje potenciál pre d'alšiu expanziu nielen nami posudzovanej spoločnosti. Len v našom výskume sme definovali 76 obcí vhodných pre výstavbu maloobchodných prevádzok rôznych formátov v rôznom počte.

Do budúcnosti odporúčame okrem d’alšej výstavby kamenných obchodov aj implementáciu využitia súčasného elektronického obchodu pre celé územie Slovenska a kooperáciu aj menších prevádzok pri vybavovaní objednávok. Elektronický obchod by umožnil spoločnosti zlepšit' svoje postavenie a vyplnit' tak medzeru na trhu voblasti maloobchodného predaja potravín na internete. Umožnil by tiež obsluhovat' aj vzdialenejšie územia s menšou hustotou obyvatel'stva a priviedol by nových zákazníkov, najmä mladých l'udí vyhl'adávajúcich pohodlnejší spôsob nákupu. Najväčšou výhodou plynúcou z rozšírenia elektronického obchodu je, pravdaže, zníženie nákladov na prevádzku a rozšírenie obsluhovaného územia.

Taktiež je potrebné zamerat' väčšiu pozornost' na zákazníka a poskytované služby. Väčšina zákazníkov v súčasnosti už nehl'adá iba nízke ceny, ale najmä pridanú hodnotu vo forme kvalitných zákazníckych služieb, záručného a pozáručného servisu, ochoty personálnu riešit' vzniknuté problémy a dodržiavania sl'úbených predsavzatí. Ako vyplynulo z vlastného terénneho výskumu, zákazníci prikladajú vysokú významnost' správaniu personálu v obchode a sú kvôli nespokojnosti v tejto oblasti ochotní zmenit' svoju obl'úbenú maloobchodnú prevádzku.

\section{Literatúra}

[1] URBION: Štandardy minimálnej vybavenosti obcí. [online]. 2010. [cit. 2013-01-22]. Dostupné na internete: <http://www.urbion.sk/ww2/wpcontent/uploads/2011/01/\%C5\%A0tandardy-minim\%C3\%A1lnej-vybavenostiobc\%C3\%AD-skr\%C3\%A1ten\%C3\%A9-znenie.pdf>

[2] TESCO: Obchody.[online]. [cit. 2013-03-10]. Dostupné na internete: <http://www.itesco.sk/sk/tesco-v-sr/o-nas/profil/>

[3] SZCZYRBA, Z.; ORDELTOVÁ, M.: Současná situace v maloobchodní síti českých měst - Geografická sonda Zlín. In Urbanizmus a územní rozvoj. Ročník 4. č. 3/2006.

[4] INCOMA GFK: Češi a Slováci jsou "závisli" na slevách. [online] 2012. [cit. 2013-0216] Dostupné na internete: $<$ http://www.incoma.cz/cz/ols/reader.aspx ?msg=1213\&lng=CZ\&ctr=203> 
[5] Ročenka českého a slovenského obchodu 2010. Praha: České a slovenské odborné nakladatelství, 2010. s. 93. ISBN: 978-80-86835-06-

[6] LAUKO, V. a kol.: Potravinársky maloobchod na Slovensku: rurálne prostredie, čas a miesto nákupu. In ACTA GEOGRAPHICA UNIVERSITATIS COMENIANAE. [online]. 2008, No. 51 [cit. 2013-01-23]. Dostupné na internete: <http://www.regionalnageografia.sk/upload/personal/Lauko,\%20V.\%20a\%20kol.\%20 $\% 282008 \% 29$.pdf>

[7] GFK SLOVAKIA: Shopping monitoring GfK Slovakia. [online] [cit. 2013-02-16] Dostupné na internete: <http://www.gfk.sk/public_relations/press/press_articles/009581/index.sk.html>

[8] Osobná konzultácia k Mgr. Erikom Šiatkovským, Property Acquisition Director HU/SK/CZ TESCO STORES SR, a.s., Bratislava, 14.12.2012

[9] ĎUGELOVÁ, M.: Potenciál rozširenia maloobchodných sietí do menších obcí na Slovensku.: diplomová práca. Žilina: Žilinská univerzita v Žiline, 2013. 121s.

\section{Grantová podpora}

VEGA 1/0421/12 Modelovanie difúzie znalostí v podnikových hodnotových ret’azcoch VEGA 1/0895/13 Výskum strategického riadenia podnikov ako podpora konkurencieschopnosti v dynamickom podnikatel'skom prostredí 